\title{
Mortality in the Capture of Game Animals
}

\author{
By B. McCulloch and P. L. Achard
}

If wild animals have to be captured, should it be by modem methods with drugs or are the old methods of chasing and catching satisfactory? The authors of this paper, one from the Veterinary Investigation Centre, the other of the Game Division in Mwanza, Tanzania, describe the results of capturing game by chasing and assess the results. They found it harmless for some, disastrous for others. As so many animals are being captured today for zoos, which increase in number yearly, research stations and private parks, the FPS regards this paper as of the first importance. It is published under the joint auspices of the FPS and UFAW (Universities Federation for Animal Welfare) who generously made a grant for its publication.

A $\mathbf{N}$ increasing number of reports tend to suggest that the capture A of wild animals by conventional methods is outdated, and that to chase and rope animals, to dazzle by spotlight and rope, or to catch by hand and to net, should give way to dart techniques as described in recent publications $(5,9,11,12)$. The majority of professional game catchers, however, still hold to conventional methods, as did the Fauna Preservation Society in "Operation Oryx" $(4,16)$ and the Kenya Game Department for Hunter's antelope, described in ORYX (4a). The Game and Veterinary Divisions of the Government of Tanzania are at present investigating the mortality resulting from the capture of wild animals by conventional methods, with a view to assessing the mortality directly related to the method of capture, as distinct from mortality caused by disease or management practice. The investigation is connected with the need to stock the recently created game reserve of Saanane Island, and the proposed new game reserve Rubondo Island (6), both in Lake Victoria. Mr. Carr Hartley, a professional catcher, has kindly provided a team who catch most of the animals; the Game Division is responsible for their care, management and feeding.

In this interim report our observations for the year 1964 are recorded. Most of the information has been presented comprehensively in the form of tables which have been printed separately. These can be obtained free of charge from the Fauna Preservation Society, c/o Zoological Society of London, Regent's Park, London, N.W.1, or from UFAW, 7a Lamb's Conduit Passage, London, W.C.1.

Catching operations were carried out in the Grumeti controlled area, north of the western "corridor" of the Serengeti National Park between the Grumeti and Rubana rivers, where there is much open country and open woodland. Species of Acacia and Commiphora are 
characteristic of the woody plants, and there is dense riverine vegetation. Tsetse fly Glossina swynnertoni are prevalent (10). The controlled area is noted for its wide variety of plains game, and forest species are to be found along the river margins. Although the country is largely unsettled, the grasslands and the "Mbugu" grasslands are burned annually by poachers, fishermen and honey hunters. The annual rainfall is between 30 and 40 ins. but in the 1963-64 wet season it was above average. However it is well drained, and after rain the ground rapidly becomes suitable again for catching operations. Recorded shade temperatures during the catching season ranged between $53^{\circ}$ and $91^{\circ} \mathrm{F}$. (Table 1 ).

\section{Methods of Capture}

Most captures were made in daylight by chasing the animal with one vehicle and noosing it with a rope, but two vehicles were needed to capture rhinoceros and topi. Some topi were captured at night. A lorry carrying a large crate some $12 \mathrm{ft}$. long, $6 \mathrm{ft}$. high and $5 \mathrm{ft}$. wide followed the catching cars, and an additional vehicle was required to observe the disposition of the herd being chased. Animals were either caught individually from herds, or repeated captures were made from the same herd. (Tables: column 5.) On capture, the animals were numbered, and the date recorded, together with their sex, age, length of chase, rectal temperature, and time of capture. Prophylactic drugs and vaccines were administered and blood smears were taken and recorded, after which the animals were manhandled into the crate and the time of loading recorded.

At first the captured animals were transported individually to the holding pens at Kirawira, but later, animals of the same species were loaded together and released in the pens as a group. Whenever possible, they were held in captivity for at least six weeks at either Kirawira or Mwanza before being released on Saanane or Rubondo Islands. Some of the rhinoceros were sent to Arusha for onward shipment to overseas markets. They were transported individually in crates, but all other animals were loaded and transported in bulk from Kirawira to their destination.

\section{The Holding Pens}

Pens for the animals were constructed of poles wired together, and for particularly nervous species, such as ostrich, which might damage themselves by dashing against the pen, the inside walls were padded with bundles of long grass. Each pen had a crush some $6 \mathrm{ft}$. wide and $16 \mathrm{ft}$. long attached to it, and at the outer entrance of the crush there was a ramp pit, dug sufficiently deep to ensure that when the transporting lorry was backed into it, the floor of the crate was at ground level. The crate was efficiently unloaded and reloaded by driving the animals in or out of the crate with the assistance of a large tarpaulin suspended between two men and gradually moved towards the animals, which then moved in the required direction. 


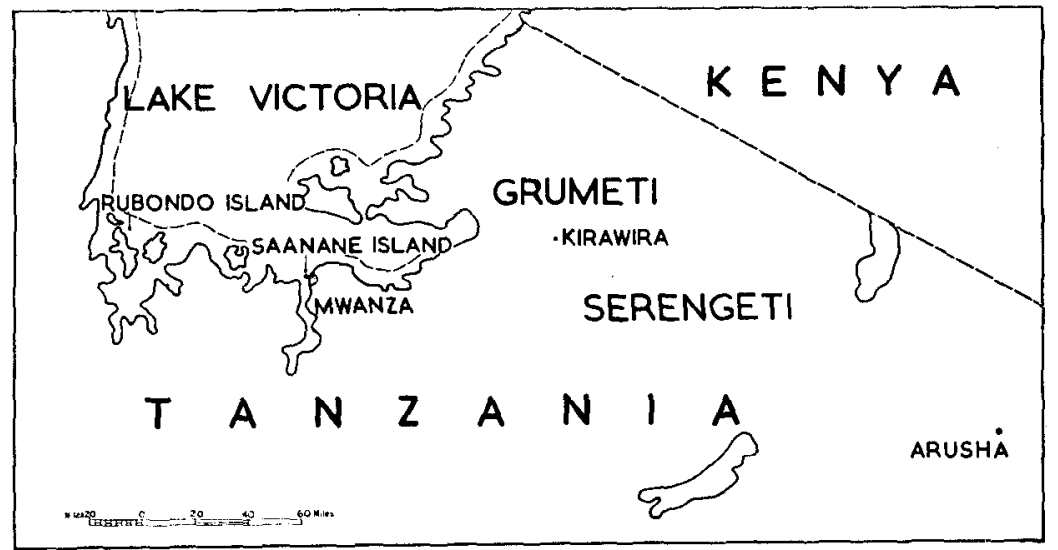

Zebra

Zebra Equus burchellii bohmi were the first animals to be captured. At a preliminary run in June, 11 zebra were caught just before the Hartley team arrived at Kirawira. Work on the species was continued with their assistance in September, when a further eight zebra were secured (Table II). At the first trial, catching operations were confined to two herds. Due to difficult terrain only the third and fourth animals which were chased in the first herd were caught. However, five successive animals were caught as planned in the second herd. Two zebra, Nos. 5629 and 5625, died within 24 hours of capture from azoturia. Zebra No. 5626 showed clinical symptoms of this disease but recovered. The three affected animals were the fourth zebra which was caught in the first herd, and the fourth and fifth zebra which were caught in the second herd. As azoturia is an easily recognisable stress condition of the horse family, it was considered undesirable to repeat these observations.

At the second trial in June, a further four zebra were caught from different herds. Two zebra, Nos. 5632 and 5633, died within 24 hours of capture. Zebra No. 5632 was accidentally struck by the capture truck, though the actual cause of death was not diagnosed. Zebra No. 5633 was subjected to excessive direct chase. Post-mortem examination showed considerable interstitial haemorrhage in the lung tissue. Zebra No. 5626, the one which had shown symptoms of azoturia, died nine days after capture. The cause of death was unknown as no postmortem examination was carried out. On the 2nd July, 1964, the remaining six zebra were bulk transported to Mwanza, where the two immatures, Nos. 5627 and 5623, died from the effects of malnutrition. The deaths occurred 17 and 38 days after capture. Zebra Nos. 5630, 5628,5621 and 5622 were in poor condition when they were released on Saanane Island on 20th August, 1964, after some nine weeks of capitivity. They were mature animals which had been subjected to a moderate chase at capture. 
Zoo requirements, however, are directed towards the younger animal and therefore eight yearling zebra were caught in September by the Hartley team. The chases were short, averaging about two minutes duration, and the animals were taken from different herds. Alternate animals were injected with $1.0 \mathrm{grm}$. di-triazine-diaceturate.* There were no deaths attributable to capture. The animals were bulk transported to Mwanza within 48 hours of capture. The first death occurred after 12 days of captivity when zebra No. 5757 died of peritonitis. Deaths from malnutrition began 19 days after capture and continued to the 27th day. During this period five zebra died: Nos. $5750,5758,3431,3432$ and 3433. The two surviving zebra, Nos. 5759 and 3741, were released on Saanane Island on the 15th December, 1964 , after six weeks of captivity.

The zebra were found to eat mostly grass during their period of capitivity. They ate no browse. The animals which were caught in June took to grain feeding. Those which were caught in September, refused this supplement.

\section{Giraffe}

Three giraffe Giraffa camelopardalis tippelskirchi of varying ages were caught in June and July before the arrival of the Hartley team (Table III). One animal was chased and caught in one herd and two animals were chased and caught in a second herd. The animals were vaccinated with anthrax, haemorrhagic septicaemia and blackquarter vaccines, and injected with $2.0 \mathrm{grm}$. di-triazine-diaceturate, $50 \mathrm{ml}$. sulphadimidinet and $20 \mathrm{ml}$. mepyramine.

There were no deaths attributable to capture. They were bulk transported to Mwanza within 72 hours of capture. During transit through Mwanza township, giraffe No. 5635 was electrocuted by a flash-over of 11,000 volts from a town supply transformer. Giraffe Nos. 5634 and 5647 maintained excellent condition in captivity, some seven weeks, and were released on Saanane Island on the 19th August, 1964. The giraffe were found to eat mostly browse during their period of captivity. They ate some grass and took to supplementary grain feeding.

\section{Wildebeest}

Nine yearling wildebeest Gorgon taurinus hecki were caught in July by the Hartley team (Table IV). Two animals were chased and caught in one herd and seven animals in a second herd. They were vaccinated with anthrax, haemorrhagic septicaemia and blackquarter vaccines. There were no deaths attributable to capture. The animals were held at Kirawira for a period of 59 days. The first death occurred 42 days from capture when wildebeest No. 5638 died from the effects of malnutrition. Two more, Nos. 5639 and 5617, died at Kirawira. The remaining six were bulk transported direct to Saanane Island

* Berenil: Bayer.

† Sulphamezathine: Imperial Chemical Industries Ltd.

‡ Anthisan: May \& Baker Ltd. 
and released on the 12th September, 1964, after seven weeks of captivity. Unfortunately deaths from the effects of prolonged malnutrition continued after the animals had been released, and three nore died, Nos. 5618, 5614 and 5637. The wildebeest were found to eat only grass during their period of captivity. They ate no browse or supplementary grain feed.

\section{Topi}

Thirteen topi Damaliscus korrigum jimela were caught in July and August by the Hartley team (Table V). Eight yearlings were chased and caught in July. Up to two animals were chased in the same herd. Three animals were vaccinated with anthrax, haemorrhagic septicaemia and blackquarter vaccines. Four including the vaccinated animals were injected with $0.5 \mathrm{grm}$. di-triazine-diaceturate and $50 \mathrm{ml}$. sulphadimidine. There were no immediate deaths, and the animals were bulk transported to Mwanza within 48 hours of capture. The first deaths occurred 5 and 7 days after capture when topi, Nos. 5685 and 5688 died from malnutrition. The deaths continued and all the topi died from malnutrition, the last one 28 days after capture.

In August, a further five yearlings were caught, the first two by the spotlight method at night; the other three were chased and caught in the usual manner. Two were vaccinated with haemorrhagic septicaemia and blackquarter vaccines, and injected with $0.2 \mathrm{grm}$. di-triazine-diaceturate, $50 \mathrm{ml}$. sulphadimidine and $10 \mathrm{ml}$. methyridine.* There were no deaths immediately after capture, and the animals were bulk transported to Mwanza within 48 hours. The first deaths occurred three and four days after capture when three, Nos. 5670, 5678 and 5677 , died in a state of malnutrition. Gross lesions of muscular dystrophy were found in the post-mortem examinations. In view of this earlier onset of malnutrition the two remaining topi were released on Saanane Island on 31st August, 1964, after only four days of captivity, but both died a short time after release. No post-mortem examinations were carried out, but it was assumed that their deaths were due to malnutrition. The topi were found to eat only grass during their periods of captivity. They ate no browse or supplementary grain feed.

\section{Eland}

Seven yearling eland Traurotragus oryx pattersonianus were caught in July by the Hartley team (Table VI). Six animals were chased and caught in one herd and one animal was chased and caught in a second herd. Alternate animals were vaccinated with anthrax, haemorrhagic septicaemia and blackquarter vaccines, and vaccinated animals were injected with $0.5 \mathrm{grm}$. di-triazine-diaceturate and $30 \mathrm{ml}$. sulphadimidine. There were no deaths attributable to capture, and the animals were bulk transported to Mwanza within 48 hours of capture. There were no deaths during the seven weeks of captivity,

- Promintic: Imperial Chemical Industries, Ltd. 
and the animals were in excellent condition when released on Saanane Island on the 12th September, 1964. In captivity the eland were found to eat mostly browse. They ate some grass, but took no supplementary grain feed.

\section{Buffalo}

Five yearling buffalo Syncerus caffer caffer were caught in July and August by the Hartley team (Table VII). Two were chased and caught in one herd and three animals in a second herd. The animals were vaccinated with haemorrhagic septicaemia and blackquarter vaccines, and injected with $0.5 \mathrm{grm}$. di-triazine-diaceturate and $30 \mathrm{ml}$. sulphadimidine. There were no deaths attributable to capture.

One death occurred shortly after capture; No. 5705 died during an attempt at bottle-feeding. Post-mortem findings were vague. There was no pulmonary inhalation and it was assumed that the cause of death was heart failure. An examination of stomach contents showed that the animal had eaten large amounts of vegetation, so no attempt was made to bottle-feed the other buffaloes. The animals were bulk transported to Mwanza some three and five weeks after capture. There were no further deaths during their seven and nine week periods of capitivity, and they were in excellent condition when they were released on Saanane Island on the 26th September, 1964. In captivity they ate only grass, with no browse or supplementary grain feed.

\section{Ostrich}

Ten ostrich Struthio carmelus massaicus of varying ages, mostly yearlings, were caught in September by the Hartley team (Table VIII). Initially one bird was chased and caught in one flock, and three birds were chased and caught in a second flock. They were not offloaded at Kirawira but were bulk transported to Mwanza within 24 hours of capture. Three died shortly after arrival at Mwanza. On post-mortem examination, Nos. 5661 and 5641 were found to have dislocations of their necks between the 12th and 16th cervical vertebrae. The third bird No. 5643 was found to have a dislocated stifle. The surviving ostrich No. 5642 died from malnutrition a few days after it was released on Saanane Island on the 19th September, 1964, after two weeks of captivity.

Later in the month two birds were chased and caught in one flock and four in separate flocks. They were kept at Kirawira, and shortly after capture there were three deaths. Post-mortem examination showed that two of them, Nos. 5751 and 5755, had dislocations of the lower neck. The third, No. 5772, had a haemorrhage in the lung. The death of a fourth ostrich, No. 5753, some nine days after capture, was also attributed to catching procedure, as it sustained a neck injury which prevented it feeding properly. The two survivors were bulk transported to Mwanza on the 3rd November, 1964, and were in excellent condition when they were released on Saanane Island on the following day, after six weeks of captivity. These two ostriches were found to 
eat grass, browse and supplementary grain feed during their period of captivity.

\section{Rhinoceros}

Eight rhinoceros Diceros bicornis bicornis were chased and caught on separate days in February, July and August by the Hartley team (Table IX). Depending on age, they were injected with 1.5 to $3.0 \mathrm{grm}$. di-triazine-diaceturate.

There were no deaths attributable to capture, and they were transported singly to Mwanza, Arusha, Rubondo Island and Saanane Island. One died in captivity. No. 3435 broke into the pen of a young male rhinoceros No. 3434; in the ensuing fight the young animal sustained serious injuries to his lower lip and jaw, and died two weeks later. The other seven were in excellent condition when they were dispatched to their various destinations. They were found to eat mostly browse during their periods of captivity, with some grass but no supplementary grain feed.

\section{ANIMAL HEALTH}

The captured animals tended to show rises in rectal temperatures with increased physical exertion, but there were considerable individual variations in this response, and there appeared to be no correlation between rectal temperature and mortality. At the time of capture a variety of drugs and vaccines were administered prophylactically with no untoward effects, but no apparent benefit. This may have been due to the present limited disease challenge in the holding pens, and to sporadic tick control achieved by spraying the animals with ixodicide.*

Thick and thin blood films were prepared at the time of capture from a number of the animals. Three out of nine zebra showed Babesia in their blood smears. Piroplasms of the Theileria type or of the Cytauxzoon hype (2) were seen in the smears of one out of eight topi and six out of seven eland. The one slide which was prepared from buffalo showed Anaplasma and Theileria (Cytauxzoon). No protozoal parasites were seen in the blood films of wildebeest or giraffe. No slides were prepared from rhinoceros or ostrich.

Post-mortem examinations were carried out on most of the animals which died. Smears of brain, spleen and blood were prepared and examined, and occasional histopathological and bacteriological examinations were carried out. The results have not been recorded in the tables in view of the clear cut nature of the gross pathological findings. Many internal parasites were seen in the post-mortems. All the zebra carried larvae of the bot fly Gastrophilus in their stomachs, and worms of the genus Strongylus in their large intestines. Lungworms of the genus Dictyocaulus and an unidentified worm which caused circumscribed, raised, greenish-yellow lesions in the lungs, were observed in some of the topi and wildebeest. A somewhat similar lesion is described by Urquhart and others (14).

* Delnav: Cooper, McDougall and Robertson, Ltd. 
Malnutrition, which may have been aggravated by internal parasitism, was the most common condition. In general, the affected animals ate well and were active to within an hour or so of death. Topi and zebra showed symptoms of muscular weakness in the 12 to 24 hours before death. Post-mortem examinations showed full stomachs, and both the stomachs and bowels contained normal ingesta. The carcases were emaciated. The cardiac, omental, perirenal, intermuscular and subcutaneous fat deposits were completely depleted. The fat stroma contained gelatinous straw coloured fluid.

The zebra which succumbed to azoturia showed stiffness and incordination of gait, and collapse was followed by death. Full bladders were found on post-mortem examination. The urine was dark brown, albuminous, and of the consistency of a thick soup. Azoturia is fully described by Davies (3).

Gross lesions of muscular dystrophy were observed in three of the 11 post-mortem examinations on topi. The characteristic whitishyellow streaks of muscle degeneration were seen in the fore and hind legs, and small discrete whitish foci were seen on the ventricles of the hearts. Muscular dystrophy has been described in Hunter's antelope by Jarret and others (7).

\section{DISCUSSION}

It is difficult to compare the capture of wild animals by the drug and dart technique with their capture by conventional methods. The reports in the literature on the use of immobilising drugs have had varied objectives and the work has been carried out in different areas, under different conditions. The survival rate of capture followed by immediate release is almost certain to be better than that of capture followed by prolonged captivity. As professional catchers usually have to keep their animals for some three to six weeks before shipment overseas, it was decided to simulate these conditions as far as possible in this trial, and animals were held in captivity for at least six weeks before they were released on the islands or sent to Arusha.

In general the mortality which occurred after chasing and noosing can be separated into immediate mortality, related to this method of capture, and delayed mortality, associated with the management of the animals. When a herd was sufficiently large the chase was sustained within the herd, and the effects of indirect stress were thus observed. It became evident that excessive chasing of zebra resulted in deaths from azoturia. These deaths appeared avoidable, provided that the capture was effected quickly, and that not more than one animal was taken from a herd. There were no deaths of wildebeest or eland after prolonged chasing.

No deaths attributable to capture occurred in giraffe, buffalo or rhinoceros, but no observations were made on the effects of excessive chasing of these species. There were no deaths of topi immediately after capture. However, some of the animals which died later from malnutrition showed lesions of muscular dystrophy, and their deaths 
may have been precipitated by this condition. The capture of both yearling and mature ostrich was attended by heavy mortality. Death usually followed dislocation of the neck, and variations in the length of chase appeared to have little effect on the outcome. As a result, work on this species was abandoned to await the hatching of some younger birds.

It should be noted that only one animal died during actual capture; zebra No. 5633. Had the other 73 animals and birds been marked and released immediately after capture, the recorded mortality would have been 1.3 per cent.

By and large, most of the deaths which occurred were delayed and were attributable to malnutrition. Losses were particularly heavy in young zebra, topi and wildebeest-grassland grazers. These animals ate only grass during their periods of captivity. The only available grasses which they would eat were of low nutritional value. No lucerne or quality hay was available to supplement the diet. The rapid onset of malnutrition in the topi which were caught in August suggested that the animals were undernourished in their natural surroundings, and this was confirmed. Four topi were shot and examined, and three found to be in poor condition, with little or no development of fat in the cardiac, omental or perirenal tissues. This may have been caused by the scarcity of grazing, the result of widespread bush fires.

There were no losses from malnutrition among the buffalowoodland grazers probably due to two factors. Firstly, they ate in addition to the available grasses, large quantities of elephant grass, which is reputed to be of high nutritional value, and secondly, that they had been grazing before capture on riverine vegetation which was unaffected by burning.

The giraffe, eland and rhinoceros-woodland browsers-maintained excellent condition throughout capitivity; they ate large amounts of tree and shrub foliage. Work done by Wilson and Bredon $(1,15)$ on the chemical composition of plants in Karamoja, Uganda, indicates that the inclusion of browse in the diet favours the intake of crude protein.

It is clear therefore, that in the important days of early captivity, little or no basic change in the food preferences of the animals occurred. The animals remained essentially grass or browse eaters as observed by Lamprey (8). As only giraffe took readily to supplementary grain feed, it is necessary to investigate the food requirements of wild animals following their capture, bearing in mind the nutritional state of the animal in its environment, its specific food selections, and the availability of such preferences for feeding during shipment overseas.

It is interesting to note that there appeared to be no correlation between the shade temperature at the time of capture and the occurrence of deaths, and that there were no deaths from common protozoal diseases. The widespread presence of protozoal parasites in 
blood films prepared from healthy wild animals at capture, suggests that their demonstration in the blood of sick or dead animals may be of limited importance, unless the observation is accompanied by careful clinical or post-mortem examination.

It is usual for animals which are freshly caught to be apprehensive and easily excited. For this reason they are generally transported in tight-fitting individual crates and frequently tranquillised. During this trial, however, animals were by and large transported in bulk. The freshly caught animal was of course alarmed in the large crate by itself, but it settled down as soon as it was joined by another of the same species. The addition of others to the crate, albeit of different herds, further encouraged the re-establishment of a gregarious herd instinct; the animals behaved in an orderly manner, and it was found unnecessary to administer tranquillising drugs. A fairly large number of groups of animals have now been transported many miles in this way. Provided that they were able to move freely in the crate, there was no biting, kicking, horning or fighting. They travelled well and arrived at their destination without a scratch. With bulk transportation the physical handling of animals was reduced to a minimum; it was only necessary to touch the animals at capture. All subsequent movement in or out of crates and pens was effected simply with the assistance of a tarpaulin. No observations have been made as yet on the individual transportation of tame or partially tame animals, as would be required for shipment overseas.

\section{SUMMARY}

The majority of the wild animals captured were chased by vehicle and noosed with a rope. There were no deaths associated with the capture of wildebeest, eland, rhinoceros, buffalo and giraffe. Zebra deaths followed excessive chasing and bad catching technique. It was noted that topi may also be unsuitable subjects for a prolonged chase, and this method proved unsatisfactory also for the more mature ostrich. Deaths occurring later in captivity were mainly due to malnutrition. Losses were highest in wildebeest, topi and zebra, all grassland grazers. There were no losses from this condition in rhinoceros, eland or giraffe, all woodland browsers, nor in buffalo, which are woodland grazers. The bulk transportation of naturally gregarious animals was found to be safe and effective.

\section{ACKNOWLEDGMENTS}

We are grateful for the help which we have received from Mr. T. Carr Hartley, and his sons Roy and Michael. We would like to thank Mr. M. Murray, who carried out histopathological examinations, and $\mathbf{M r}$. $\mathrm{R}$. Tungaraza and Mr. S. K. Kasimbala for technical assistance. We are indebted to Dr. P. Jordan, Director, East African Institute for Medical Research, Mwanza, for permission to build the holding pens in the Institute grounds, and to His Excellency, Mr. J. S. Malecela, late of the Regional Administration, for his constant help and encouragement. We are also grateful to the Chief Game Warden, Mr. H. S. Mahinda, and the Director, Veterinary Division, Mr. T. S. Lwebandiza, for permission to publish. 
the evolution and behaviour of the shark

\section{About Sharks and Shark Attack}

DAVID H. DAVIES, Director, The Oceanographic Research Inst., Durban

A fascinating work covering the biology of sharks, their behaviour, attacks on human beings, anti-shark research and many other matters. The book contains a wealth of scientific findings and is profusely illustrated - 64 black and white and ten full-colour photographs. 40s.

from your bookseller or direct from Kegan Paul, Trench, Trubner \& Co. 43 Great Russell Street, London, W.C.I

ROUTLEDGE \& KEGAN PAUL

\section{READ}

\section{AUDUBON MAGAZINE}

America's popular, authentic and educational nature publication. Leading writers and photographers. Subscription rate $\$ 7.00$ per year for 6 colourful issues.

NATIONAL AUDUBON SOCIETY

1130 FIFTH AVENUE

NEW YORK, N.Y. 10028. 


\section{REFERENCES}

1. BREDON, R. M. and WILSON, J. (1963). The chemical composition and nutritive value of grasses from semi-arid areas of Karamoja as related to ecology and types of soil. E. Afr. agric. for. J. 29: 134-142.

2. BROCKLESBY, D. W. (1962. Cytauxzoon taurotragi Martin and Brocklesby 1960 , a piroplasm of the eland (Taurotragus oryx pattersonianus Lydekker, 1906). Res. Vet. Sci. 3: 334-344.

3. DAVIES, G. O. (1955). Veterinary Pathology and Bacteriology. 4th Ed. London.

4. GRIMWOOD, I. R. (1962). Operation Oryx. ORYX 6: 308-334.

4a. 1964. Airlift for Hunter's antelope: rescue operation in Kenya, ORYX 7: 164-167.

5. HARTHOORN, A. M. (1963). Modern trends in animal health and husbandry: ataractic, hypnotic and narcotic mixtures for the capture and handling of large wild animals. Brit. vet. J.: 119: 47-63.

6. IRWIN, T. (1964). Want to adopt a rhino? Africana 2: 13-15.

7. JARRET, W. H. F., JENNINGS, F. W., MURRAY, M. and HARTHOORN, A. M. (1964). Muscular dystrophy in wild Hunter's Antelope. E. Afr. Wildl. J. 2: 158-159.

8. LAMPREY, H. F. (1963). The ecological separation of the large mammal species in the Tarangire Game Reserve, Tanganyika. E. Afr. Wildl. J. 1: 63-92.

9. ORR, D. J. C. and MOORE-GILBERT, S. M. (1964). Field immobilisation of young wildebeest with succinylcholine chloride. E. Afr. Wildl. J. 2: 60-66.

10. POTTS, W. H. (1937). The distribution of Tsetse flies in Tanganyika Territory. Bull. Etn. Res. 28: 129-148.

11. SHORT, R. V. and KING, J. M. (1964). The design of a crossbow and dart for the immobilisation of wild animals. Vet. Rec. 76: 628630.

12. TALBOT, L. M. (1960). Field immobilisation of some East African wild animals and cattle. E. Afr. agric. for. J. 26: 92-102.

13. TANGANYIKA (1965). Atlas of Tanganyika, 3rd Ed. Dept. of Lands and Survey. Dar es Salaam.

14. URQUHART, G. M., HAY, D., ZAPHIRO, D. R. P. and SPINAGE, C. A. (1960). Some internal parasites of game animals in Kenya. E. Afr. agric. for. J. 26: 11-20.

15. WILSON, J. G. and BREDON, R. M. (1963). Nutritional value of some common cattle browse and fodder plants of KaramojaNorthern Province, Uganda. E. Afr. agric. for. J. 28: 204-208.

16. WOODFORD, M. H. (1963). Translocation-A method of saving a species in danger of extinction. Vet. Rec. $75: 219-222$.

\section{Pesticides in Gardens}

A leaflet stating which pesticides the Minister of Agriculture has advised should not be used by gardeners has been published by the British Section of the International Council for Bird Reservation (British Museum, Natural History, London, S.W.7) and the Royal Society for the Protection of Birds (The Lodge, Sandy, Beds.), and copies will be supplied free by either body. 